\title{
Atmospheric deposition control of soil acidification in central Italy
}

\author{
G. Cecchini ${ }^{\text {a }}$, A. Andreetta ${ }^{\mathrm{a}, *}$, A. Marchetto $^{\mathrm{b}}, \mathrm{S}$. Carnicelli ${ }^{\mathrm{a}}$ \\ a Dipartimento di Scienze della Terra, Università di Firenze, Piazzale delle Cascine 15, 50144 Firenze, Italy \\ ${ }^{\mathrm{b}}$ CNR Istituto per lo Studio Degli Ecosistemi, Largo Tonolli 50, 28922 Verbania Pallanza, Italy
}

\section{A R T I C LE INFO}

Keywords:

Soil acidification

Base cation deposition

Canopy budget

Mediterranean

Forest soils

\begin{abstract}
A B S T R A C T
Acidification is a major soil-forming process, and concerns about acidifying anthropogenic atmospheric deposition make it a significant environmental issue. In the long term, the depletion of exchangeable base cations (BCEs) is the main process underpinning soil acidification. In south-central Italy, acidic soils are not rare and are often located in areas with no excess rainfall over potential evapotranspiration. Many such soils are understood to have been derived from long-term weathering, although whether acidification is an active process remains an open question.

Data from the International Co-operative Programme (ICP-Forests) monitoring system revealed that BCE atmospheric deposition was high and stable in south-central Italy and allowed us to estimate the BCE budget of some acidic forest soils. We estimated the overall BCE budget of four sites in this network. Tracer approaches using conservative ions, $\mathrm{Na}^{+}$and $\mathrm{Cl}^{-}$, were calibrated to estimate dry BCE deposition and soil water fluxes. The contribution of atmospheric deposition to the BCE budget was such that potassium was found to be regularly accumulating at all sites at the rate of 0.08 to $0.42 \mathrm{~g} \cdot \mathrm{m}^{-2} \cdot \mathrm{y}^{-1}$, while calcium was accumulating at a rate of $1.11 \mathrm{~g} \cdot \mathrm{m}^{-2} \bullet \mathrm{y}^{-1}$ at a central Italy site. For $\mathrm{Ca}^{2+}$ at the other sites and for magnesium at all sites, the effect of deposition was such that the rate of BCE depletion was significantly reduced. Soil acidification appeared to be a non-active process in the central, lowland and hilly areas of Italy.
\end{abstract}

\section{Introduction}

The loss of basic, exchangeable cations ( $\mathrm{Ca}, \mathrm{Mg}, \mathrm{Na}, \mathrm{K}$ ) through leaching is a general trend of soil formation. The main soil classification systems (Soil Survey Staff, 1999; IUSS Working Group WRB, 2006) use base saturation (BS) of the exchange complex or total reserve in bases (TRB, Herbillon, 1986) as major parameters for defining soil types with a high degree of weathering. A well-documented case in soil taxonomy is the separation of Alfisols and Ultisols; Smith (1986) explained that this was due to the intention to separate argillic soils on glaciated (i.e., young) landforms, in which BS is controlled by the initial BCE pool, from those on unglaciated (i.e., old) ones, in which such a pool has been depleted and a steady state has been reached through BCE recycling by vegetation.

Slessarev et al. (2016) outlined climatic factors as the main determinant of soil $\mathrm{pH}$, acting primarily through calcium depletion; deviations from climatic control ("outliers") were interpreted as being primarily due to anomalously high or low initial Ca reserves. With some exceptions, the depletion of BCE results in soil acidification and im- paired plant nutrition; additionally, BS is considered by pedologists as the most significant indicator of soil acidity due to its robustness and slow, usually monotonic, evolution. TRB has been proposed to assess the acid neutralization capability (ANC) (Van Breemen et al., 1983) of soils (Brahy et al., 2000). Chesworth $(1983,1992)$ and Macias et al. (2008) proposed a major soil weathering model, "the acid trend", i.e., a natural trend to soil acidification, as the prevailing evolution of freely draining soils in moist climates.

Scholars studying soil acidification in the context of atmospheric pollution, focusing on glaciated lands of the northern hemisphere, initially tended to emphasize soil and soil solution $\mathrm{pH}$ as an acidification indicator (Ulrich, 1983; Robarge and Johnson, 1992). Later reviews (Van Breemen et al., 1983; Tomlinson, 2003), however, stressed the depletion of BCEs as the major effect and indicator of acidification. Similarly, the rate of weathering was initially emphasized as controlling the soil response to acidifying inputs (Ulrich, 1986); other authors, however, pointed out that weathering kinetics are too slow for this role (Chadwick and Chorover, 2001; Slessarev et al., 2016). Pedology has always implicitly acknowledged the concept that BCE leaching is a

\footnotetext{
* Corresponding author.

Email address: anna.andreetta@unifi.it (A. Andreetta)
} 
Table 1

Site characteristics. Bulk deposition of base cations $\left(\mathrm{BD}_{\mathrm{BCE}}\right)$ and throughfall deposition of base cations $\left(\mathrm{TFD}_{\mathrm{BCE}}\right.$ ). Total thickness of the forest floor (FF). Samplings up until 31/12/ 2015.

\begin{tabular}{|c|c|c|c|c|}
\hline $\begin{array}{l}\text { Site (ICP-Forest } \\
\text { ID) }\end{array}$ & $\begin{array}{l}\text { LAZ1 } \\
\text { (IT9) }\end{array}$ & EMI1 (IT5) & $\begin{array}{l}\text { PIE1 } \\
\text { (IT12) }\end{array}$ & $\begin{array}{l}\text { VEN1 } \\
\text { (IT20) }\end{array}$ \\
\hline \multirow[t]{2}{*}{ Position } & $42^{\circ} 49^{\prime} \mathrm{N}$ & $44^{\circ} 43^{\prime} \mathrm{N}, 10^{\circ} 12^{\prime} \mathrm{E}$ & $45^{\circ} 41^{\prime} \mathrm{N}$ & $46^{\circ} 03^{\prime} \mathrm{N}$ \\
\hline & $11^{\circ} 54^{\prime} \mathrm{E}$ & & $8^{\circ} 04^{\prime} \mathrm{E}$ & $12^{\circ} 01^{\prime} \mathrm{E}$ \\
\hline Vegetation & $\begin{array}{l}\text { Quercus } \\
\text { cerris }\end{array}$ & $\begin{array}{l}\text { Quercus pubescens } \\
\text { - Q cerris. }\end{array}$ & $\begin{array}{l}\text { Fagus } \\
\text { sylvatica }\end{array}$ & $\begin{array}{l}\text { Fagus } \\
\text { sylvatica }\end{array}$ \\
\hline Altitude, $\mathrm{m}$ asl & 675 & 225 & 1150 & 1125 \\
\hline $\begin{array}{l}\text { Sampling start, } \\
\text { deposition }\end{array}$ & $20 / 5 / 97$ & $3 / 6 / 97$ & $3 / 6 / 97$ & $27 / 5 / 97$ \\
\hline $\begin{array}{l}\text { Sampling start, } \\
\text { soil solution }\end{array}$ & $1 / 9 / 99$ & $1 / 1 / 10$ & $2 / 8 / 06^{a}$ & $15 / 6 / 10^{\mathrm{a}}$ \\
\hline Rainfall (mm) & 1019 & 859 & 1811 & 1420 \\
\hline $\begin{array}{l}\mathrm{BD}_{\mathrm{BCE}} \\
\quad\left(\mathrm{kg} \cdot \mathrm{ha}^{-1} \cdot \mathrm{y}^{-1}\right)\end{array}$ & 29.2 & 12.6 & 5.3 & 13.6 \\
\hline $\begin{array}{l}\mathrm{TFD}_{\mathrm{BCE}} \\
\quad\left(\mathrm{kg} \cdot \mathrm{ha}^{-1} \cdot \mathrm{y}^{-1}\right)\end{array}$ & 56.8 & 36.2 & 12.3 & 36.4 \\
\hline FF thickness $(\mathrm{cm})$ & 4.5 & 3.0 & 2.5 & 3.0 \\
\hline
\end{tabular}

${ }^{\circ}$ Year-round for soil solution sampling.

a May to November only for soil solution sampling.

rate-based process depleting a fixed initial stock, which will ultimately overtake mineral weathering supply.

Atmospheric transport and deposition of solid matter and solutes, of which BCEs are a major component, has seen growing recognition in the context of climate change studies. Atmospheric dust and aerosol depositions are heavily dependent on climate and have increased to fairly high levels in the last 5000 years (Le Roux et al., 2012; Vet et al., 2014a, 2014b; Albani et al., 2015). Southern Europe has been identified as a major receiving area (Avila and Rodà, 1991; Avila and Peňuelas, 1999; Guerzoni et al., 1999; Rogora et al., 2004; Kishcha et al., 2011; Morales-Baquero et al., 2013) due to the proximity of the Saharan source and, according to Ehrmann et al. (2017), the present-day dust deposition levels in Italy are among the highest throughout the Late Quaternary.

Significant effects of BCE deposition on the chemistry of natural waters in Italy, such as increased $\mathrm{pH}$ and alkalinity, have been reported for lakes (Rogora et al., 2004) and groundwater (Manca et al., 2015). More generally, the influence of atmospheric BCE deposition on ecosystems has been acknowledged in various fields of environmental research (Field et al., 2010). Acknowledgement of similar effects on soils evolved primarily through studies of forestry sustainability. Chadwick et al. (1999) first outlined the role of atmospheric deposition in the sensitive context of forestry in Pacific islands; they pointed out that rock-derived elements are lost without replacement, while atmospherically derived elements can be continuously replenished, which means that atmospheric deposition can be particularly important, especially for strongly weathered soils. The development of large-scale monitoring networks, focusing on anthropogenic acidifying deposition, has provided more information. Lee et al. (1999) produced an early Eu- rope-wide assessment, pointing out the role of anthropogenic calcium deposition sources; similarly, Watmough et al. (2014) discovered out that "BCE pollution" can effectively balance acidifying depositions. A review of the impact of atmospheric deposition on European forests (Lequy et al., 2012) evidenced these depositions as a major but neglected component of the soil BCE budget, thus outlining the need for further investigation. Studies following different approaches (Eger et al., 2013; Hynicka et al., 2016) have further supported the importance of atmospheric deposition in forest BCE budgets. Recently, the soil BCE input-output budget has been proposed as a major diagnostic tool to assess forestry sustainability (Tomlinson, 2003; Lequy et al., 2012).

Recovery of forest soils from acidification under decreasing acidifying deposition has been found to be inhibited by simultaneous decreases in BCE deposition (Likens et al., 1996; Alewell et al., 2000; Folster et al., 2003; Vanguelova et al., 2010; Meesenburg et al., 2016); this phenomenon is being thoroughly assessed by a European-wide study (Johnson et al., 2018). The influence of atmospheric BCE deposition on soil development has, however, received limited attention. The heavy influence of atmospheric deposition on southern European soils was proposed by Stuut et al. (2009); in Italy, Iamarino and Terribile (2008) and Mileti et al. (2013) surveyed the contribution of both volcanic and nonvolcanic dust to forest soils, while Costantini et al. (2018) reviewed loess deposition, further evidencing the recent role of southern sources.

The ICP-Forests network of intensive monitoring sites has been systematically recording atmospheric deposition and chemical composition of soil solutions for approximately twenty years. According to Lequy et al. (2012), under stable deposition loads, nutrient transfer from dust to soil is bound to achieve a steady state. The type of solute flux monitoring performed at ICP-Forests sites should capture nutrient flows in forest ecosystems. In the present paper, quantification of BCE budgets was attempted for 4 ICP-Forests monitoring sites in Italy, subjected to different levels of BCE deposition. The primary aim was to assess the present rates of $\mathrm{BCE}$ depletion in the context of long-term soil evolution. We considered Italy as being representative of the Mediterranean region, where atmospheric deposition is an important source of base cations. Studies on the impact of deposition on soil solution fluxes in Mediterranean countries have been underrepresented in the literature, making BCE budget estimation challenging. We hypothesized that this should result in different BCE flux patterns compared to more northern European countries.

\section{Materials and methods}

\subsection{Study sites}

Within the Italian ICP-Forests Level II network, one site (LAZ1, IT9) offers optimal conditions for estimating the BCE budget over a 15-year period; three other sites, although offering shorter and/or partial time series, were selected because they provide useful comparisons in terms

Table 2.

Main soil characteristics of the sites.

\begin{tabular}{|c|c|c|c|c|c|c|c|}
\hline Site & Soil type & Parent material/substratum & Depth cm & CEC cmolc.kg ${ }^{-1}$ & BS $\%$ & $\mathrm{pH}$ & Texture class \\
\hline \multirow[t]{2}{*}{ LAZ1 } & Cutanic Alisol, endoleptic & Sandy wash/marls ${ }^{\mathrm{a}}$ & 10 & 13.8 & 17.5 & 4.0 & $\mathrm{~L}$ \\
\hline & & & 40 & 21.7 & 48.2 & 4.4 & $\mathrm{SiC}$ \\
\hline \multirow[t]{2}{*}{ EMI1 } & Cutanic Luvisol, epidystric & Loess/gravel & 10 & 8.9 & 22.2 & 4.2 & SiL \\
\hline & & & 60 & 15.4 & 54.6 & 4.3 & SiCL \\
\hline \multirow[t]{2}{*}{ PIE1 } & Haplic Cambisol, dystric & Debris/micaschist & 10 & 18.7 & 3.9 & 4.6 & SL \\
\hline & & & 40 & 4.4 & 15.7 & 5.4 & SL \\
\hline \multirow[t]{2}{*}{ VEN1 } & Haplic Luvisol, hypereutric & Loess/limestone & 10 & 17.3 & 49.0 & 5.8 & $\mathrm{SiC}$ \\
\hline & & & 60 & 13.0 & 100.0 & 7.4 & SiCL \\
\hline
\end{tabular}

a Strongly weathered down to $1.5 \mathrm{~m}$. 


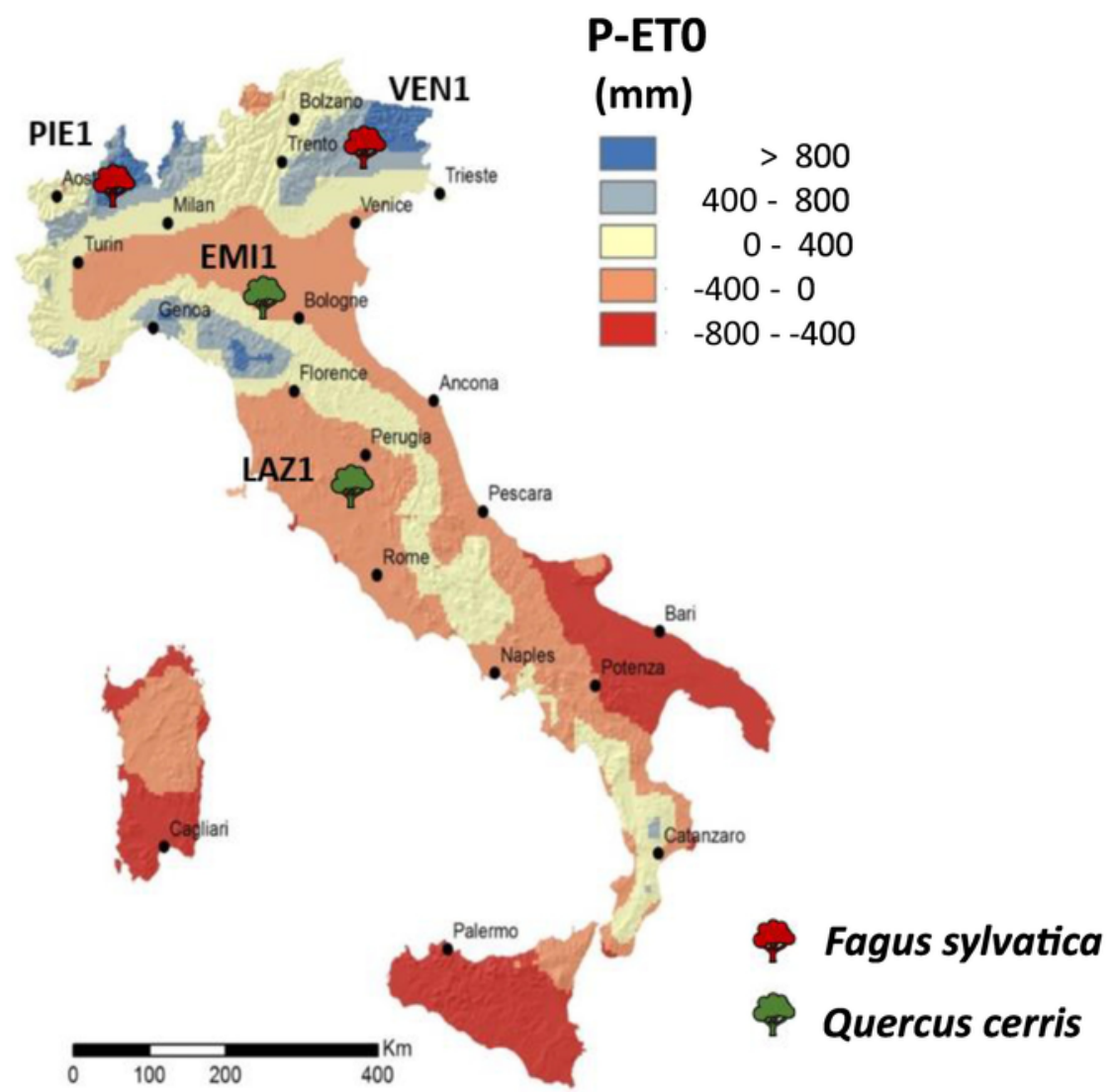

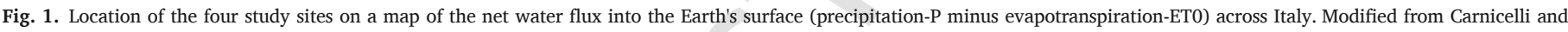
Costantini (2013).

Table 3.

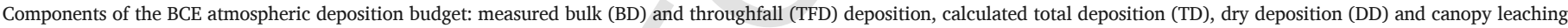

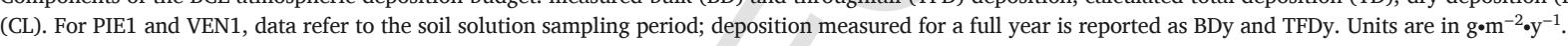

\begin{tabular}{|c|c|c|c|c|c|c|c|c|c|c|c|c|c|c|c|c|c|c|c|c|}
\hline & LAZ1 & & & & & EMI1 & & & & & PIE1 & & & & & VEN1 & & & & \\
\hline & $\mathrm{K}$ & $\mathrm{Ca}$ & $\mathrm{Mg}$ & $\mathrm{Na}$ & BCE & K & $\mathrm{Ca}$ & $\mathrm{Mg}$ & $\mathrm{Na}$ & BCE & $\mathrm{K}$ & $\mathrm{Ca}$ & $\mathrm{Mg}$ & $\mathrm{Na}$ & BCE & $\mathrm{K}$ & $\mathrm{Ca}$ & $\mathrm{Mg}$ & $\mathrm{Na}$ & BCE \\
\hline $\mathrm{BD}$ & 0.20 & 1.16 & 0.19 & 1.22 & 2.77 & 0.11 & 0.57 & 0.08 & 0.31 & 1.07 & 0.08 & 0.29 & 0.04 & 0.14 & 0.55 & 0.45 & 0.38 & 0.07 & 0.27 & 1.17 \\
\hline $\mathrm{TF}$ & 1.59 & 1.58 & 0.43 & 1.98 & 5.58 & 1.62 & 1.14 & 0.27 & 0.53 & 3.56 & 0.68 & 0.30 & 0.06 & 0.19 & 1.23 & 1.54 & 0.76 & 0.14 & 0.28 & 2.72 \\
\hline TD & 0.35 & 1.53 & 0.32 & 1.98 & 4.18 & 0.18 & 0.84 & 0.13 & 0.53 & 1.68 & 0.10 & 0.29 & 0.04 & 0.19 & 0.62 & 0.45 & 0.38 & 0.07 & 0.27 & 1.17 \\
\hline $\mathrm{DD}$ & 0.15 & 0.37 & 0.13 & 0.76 & 1.41 & 0.07 & 0.27 & 0.05 & 0.22 & 0.61 & 0.02 & 0.00 & 0.00 & 0.05 & 0.07 & & & & & \\
\hline CL & 1.24 & 0.05 & 0.11 & 0.00 & 1.40 & 1.44 & 0.30 & 0.14 & 0.00 & 1.88 & 0.58 & 0.01 & 0.02 & 0.00 & 0.61 & & & & & \\
\hline BDy & & & & & & & & & & & 0.17 & 0.56 & 0.07 & 0.30 & 1.10 & 0.57 & 0.80 & 0.14 & 0.64 & 2.15 \\
\hline TFDy & & & & & & & & & & & 1.11 & 0.57 & 0.11 & 0.36 & 2.15 & 1.95 & 1.10 & 0.23 & 0.57 & 3.85 \\
\hline
\end{tabular}

of different BCE deposition levels, climate conditions and soil characteristics (Tables 1 and 2).

In three of the four sites, Pleistocene-age soils are found. At the EMI1 (IT5) site, the soil developed on the loess cover of the Emilia Apennine margin (Maestrelli et al., 2018; Costantini et al., 2018) and has a minimum age of approximately 30.000 years. In the VEN1 (IT20) site, the soil developed on the loess cover of a limestone plateau, a cover deposited no later than the last glacial period. The soil of the LAZ1 site is interpreted as being of Pleistocene age based on its degree of development and compared with soils of known ages in similar areas (Carnicelli and Costantini, 2013; Carnicelli et al., 2015).

The LAZ1 and EMI1 (IT5) sites fall into the climatic region in which potential evapotranspiration (ETP) is higher than rainfall (ETP $>$ P, Carnicelli and Costantini, 2013, Fig. 1); the other two sites are found within the Alpine region where ETP $<$ P. Three out of four sites have acidic soils; in LAZ1 and EMI1, soil acidity is due to long-term weathering and BCE depletion, whereas the sandy soil in PIE1 (IT12) lies on debris from metamorphic rocks and is located in a high rainfall area. The soil in VEN1 is $100 \%$ base saturated, although it is free of carbonates and with a well-expressed Argic horizon. LAZ1, EMI1 and VEN1 soil represent outliers sensu Slessarev et al. (2016). Three sites are established on flat to gentle slopes; PIE1 is on a steep slope, but the soil has a very high permeability, and all sites have high rainfall infiltration with minimal runoff. All forests are deciduous high stands, offering comparable conditions for canopy budget estimation. The EMI1 site was set up as a Quercus pubescens site; however, during the 20 years of monitoring, the increasing presence of $Q$. cerris can be attributed to increased drought stresses (Bertini et al., 2011). 
Table 4.

Significant Spearman correlation coefficients $(p$ value $<0.05)$ between throughfall deposition of BCEs and $\mathrm{Cl}^{-}$, their bulk deposition (BD), throughfall and bulk precipitation (TFH and $\mathrm{BDH})$.

\begin{tabular}{lllllllll}
\hline \multirow{2}{*}{ Site } & & BDK & BDCa & BDMg & BDNa & BDCl & BDH & TFH \\
\hline \multirow{2}{*}{ LAZ1 } & TFK & & & & & & & 0.54 \\
& TFCa & & 0.8 & 0.52 & & & & \\
& TFMg & & & 0.62 & 0.57 & 0.57 & & 0.5 \\
& TFNa & & 0.52 & 0.79 & 0.80 & 0.77 & & \\
& TFCl & 0.64 & 0.61 & 0.92 & 0.9 & 0.89 & & \\
EMI1 & TFK & & & & & 0.83 & 0.77 & 0.77 \\
& TFCa & 0.89 & 0.94 & 0.71 & 0.83 & 0.77 & & \\
& TFMg & & & 0.89 & 0.83 & 0.77 & & \\
& TFNa & & & & & & & \\
& TFCl & & & & & & & \\
& TFK & & 0.72 & 0.81 & 0.79 & 0.75 & 0.84 & 0.84 \\
& TFCa & & 0.94 & 0.84 & 0.77 & 0.82 & 0.68 & 0.68 \\
& TFMg & & 0.89 & 0.89 & 0.84 & 0.85 & 0.78 & 0.78 \\
& TFNa & & 0.69 & 0.81 & 0.84 & 0.77 & 0.81 & 0.81 \\
& TFCl & 0.92 & 0.92 & 0.89 & 0.88 & 0.88 & 0.88 \\
VEN1 & TFK & & & & & & 0.63 & 0.60 \\
& TFCa & & & & & & & \\
& TFMg & 0.67 & 0.77 & & & & \\
& TFNa & & & & 0.84 & 0.80 & 0.82 & 0.78 \\
& TFCl & & & & 0.82 & 0.82 & 0.76 & 0.74 \\
\hline
\end{tabular}

\subsection{Sampling scheme and analytical methods}

The methods for sampling and analysis of atmospheric deposition and soil solutions followed standard ICP-Forests procedures, as described in UNECE-ICP (2016, and previous editions). Samples of throughfall and bulk depositions were collected weekly over the studied period (Table 1). Stemflow deposition (SFD) was not accounted for because it was only measured continuously at the F. sylvatica sites, and significant uncertainties exist in converting SFD volumes into deposition fluxes $\left(\mathrm{kg} \cdot \mathrm{ha}^{-1} \bullet \mathrm{y}^{-1}\right)$. Not accounting for SFD may have introduced a significant underestimation in the total BCE deposition estimates; data from the $F$. sylvatica sites suggested an average loss of $10-15 \%$, and the most influenced element was $\mathrm{Na}^{+}$, whose deposition peaks in the leafless season.

Samples of soil solutions were collected biweekly. Soil solution from the organic layers was sampled with gravity samplers and installed in three replicates at the forest floor-mineral soil boundary (FF samplers). At PIE1, gravity samplers were not installed due to the steep slope of the site. Soil solution from the mineral soil was sampled by cup suction samplers installed in five replicates in the topsoil $(15-20 \mathrm{~cm}$ depth) and the subsoil (60-70 cm depth).

Sample collection and analysis were subjected to strict quality assurance and quality control (QA/QC) procedures according to the guidelines of the ICP Forest Working Group on QA/QC, including use of control charts, charge balance checks and laboratory ring tests (König et al., 2013; Marchetto et al., 2011; Mosello et al., 2005). Cations were directly determined by ion chromatography. All data used have been submitted to the ICP-Forests central database and verified as compliant with quality standards.

\subsection{BCE fluxes and budget estimate}

\subsubsection{Selection of time steps}

Estimating chemical fluxes through a soil-forest system requires the selection of appropriate time steps for integration, for which Staelens et al. (2008) suggested a minimum of one month. The initial exploration of the deposition data was then based on integrating the average monthly data for the monitoring period. For matching the different sampling time steps of deposition (weekly) and soil solution (biweekly, with frequent longer intervals due to dry samplers), we established a basic time step for each day in which a forest floor soil solution sample was taken. This time step was referred to as a sampling day. Throughfall and deposition data were integrated to the next sampling day. For estimating overall soil-forest budgets, however, the use of a monthly time step implies the assumption that the soil water residence time is shorter than one month. Patterns of migration of concentration pulses from the FF to the subsoil showed that this assumption was not supported because delays of up to three months were a distinct possibility. To minimize such uncertainties, we adopted a year-like time step, exploiting the regular interruption of subsoil solution sampling due to summer drought. Year-like time steps were then set to start the day after the last subsoil sampling preceding the summer interruption and to be concluded on the last such sampling day in the next calendar year. These time steps were defined as deposition years (DYs) and were labeled after the calendar year in which they started; for example, DY 1999 began in summer 1999 and ended in summer 2000. The actual dates varied between the end of June and mid-July for the Mediterranean sites and across August for the Alpine sites; all DYs were of very similar duration. The results, in terms of budgets, should be primarily read as relative to the entire sampling period. The DY-based results are relevant for checking hypotheses and suggesting time trends.

\subsubsection{Estimating the components of the BCE canopy budget}

Total deposition (TD) was estimated by the filtering approach (Ulrich, 1983; Staelens et al., 2008; Talkner et al., 2010) using $\mathrm{Na}^{+}$as a tracer (Staelens et al., 2008). Calculations were carried out for each deposition sample, and the TD results were then integrated to each sampling day. The dry deposition factors (DDFs) for $\mathrm{Na}^{+}$and other BCEs were found to be not strictly correlated, mainly due to different seasonal deposition distributions. To prevent any possible overestimation of the total deposition, the TD amount for each cation and sampling day, used in calculating the overall budget, was taken as the minimum of the estimated TD and the measured TFD except when this resulted in a value smaller than the measured bulk deposition, in which case the BD value was used as the total deposition.

\subsubsection{Leaching output of base cations}

To estimate the water flux through the soil, we used the chloride tracer approach, according to Hruška et al. (2012). This approach is

Table 5.

Average concentrations of BCEs and $\mathrm{Cl}^{-}$and in soil solutions for each site and sampling depth.

\begin{tabular}{|c|c|c|c|c|c|c|c|c|c|c|c|}
\hline \multirow{2}{*}{$\begin{array}{l}\text { Site } \\
\text { LAZ1 }\end{array}$} & \multirow{2}{*}{$\begin{array}{l}\text { Depth }(\mathrm{cm}) \\
0\end{array}$} & \multicolumn{2}{|c|}{$\mathrm{K}\left(\mathrm{mg} \cdot \mathrm{l}^{-1}\right)$} & \multicolumn{2}{|c|}{$\mathrm{Ca}\left(\mathrm{mg} \cdot \mathrm{l}^{-1}\right)$} & \multicolumn{2}{|c|}{$\operatorname{Mg}\left(\mathrm{mg} \cdot \mathrm{l}^{-1}\right)$} & \multicolumn{2}{|c|}{$\mathrm{Na}\left(\mathrm{mg} \cdot \mathrm{l}^{-1}\right)$} & \multicolumn{2}{|c|}{$\mathrm{Cl}\left(\mathrm{mg} \cdot \mathrm{l}^{-1}\right)$} \\
\hline & & 3.39 & \pm 0.87 & 5.04 & \pm 0.99 & 1.79 & \pm 0.44 & 3.11 & \pm 0.51 & 5.78 & \pm 1.08 \\
\hline & 70 & 0.09 & \pm 0.03 & 1.63 & \pm 0.32 & 2.16 & \pm 0.18 & 9.03 & \pm 0.77 & 14.67 & \pm 1.59 \\
\hline \multirow[t]{2}{*}{ EMI1 } & 0 & 1.87 & \pm 0.41 & 4.72 & \pm 1.26 & 1.84 & \pm 0.44 & 1.24 & \pm 0.18 & 1.90 & \pm 0.24 \\
\hline & 60 & 0.03 & \pm 0.03 & 6.58 & \pm 0.39 & 2.58 & \pm 0.14 & 6.87 & \pm 1.10 & 8.12 & \pm 1.82 \\
\hline \multirow[t]{2}{*}{ PIE1 } & 0 & - & & - & & - & & - & & - & \\
\hline & 60 & 0.03 & \pm 0.01 & 0.40 & \pm 0.16 & 0.15 & \pm 0.02 & 0.30 & \pm 0.03 & 0.35 & \pm 0.04 \\
\hline \multirow[t]{2}{*}{ VEN1 } & 0 & 1.45 & \pm 0.36 & 3.75 & \pm 0.62 & 0.38 & \pm 0.09 & 0.27 & \pm 0.04 & 0.52 & \pm 0.11 \\
\hline & 60 & 0.05 & \pm 0.01 & 1.85 & \pm 0.30 & 0.24 & \pm 0.04 & 0.44 & \pm 0.04 & 0.73 & \pm 0.16 \\
\hline
\end{tabular}


Table 6.

Estimated subsoil water fluxes: throughfall precipitation (TF), $\mathrm{Cl}^{-}$input (see methods section), median $\mathrm{Cl}^{-}$concentration for the deepest lysimeter $\left(r_{C l s}\right)$ and estimated water flux $\left(J_{w s}\right)$.

\begin{tabular}{lllll}
\hline Site & $\mathrm{TF}^{\mathrm{a}}$ & $\mathrm{Cl}^{-}$input & $r_{C l s}$ & $J_{w s}$ \\
\hline & $\mathrm{mm}$ & $\mathrm{mg} \cdot \mathrm{m}^{-2} \cdot \mathrm{y}^{-1}$ & $\mathrm{mg} \cdot \mathrm{l}^{-1}$ & $\mathrm{~mm}$ \\
\hline LAZ1 & 895 & 3570 & 14.67 & 257 \\
EMI1 & 874 & 1029 & 8.12 & 133 \\
PIE1 $^{\mathrm{b}}$ & 717 & 205 & 0.35 & 585 \\
VEN1 $^{\mathrm{b}}$ & 1057 & 424 & 0.73 & 602 \\
\hline
\end{tabular}

a For the time series overlapping the soil solution sampling period.

b May to November.
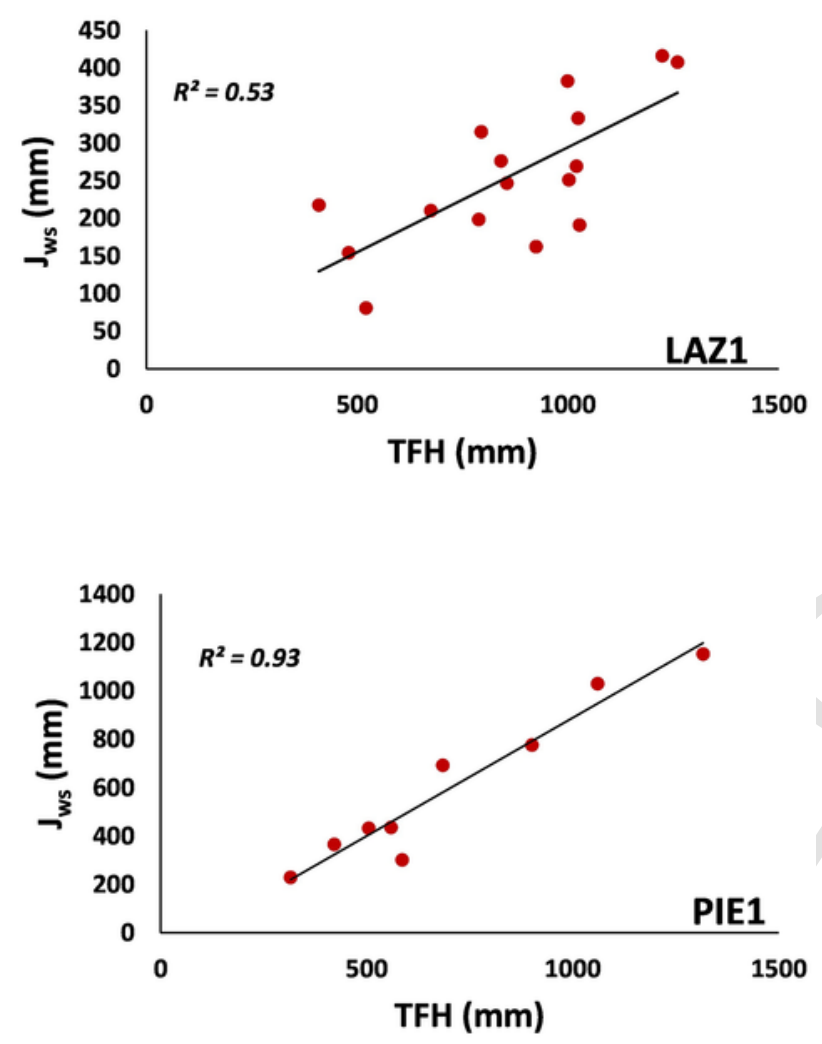

Fig. 2. Regression between estimated subsoil water fluxes $\left(\mathrm{J}_{\mathrm{ws}}\right)$ and the recorded volumes of throughfall (TFH) precipitation based on deposition years (DYs) for the LAZ1 and PIE1 sites.

suitable for the soils considered in this study because they are all fixed-charge soils with a low anion adsorption capability; given the high levels of $\mathrm{Cl}^{-}$deposition, such limited capability should be easily saturated, bringing the soil $\mathrm{Cl}^{-}$flux to a steady state.

The water fluxes for each soil layer $l$ where then calculated as follows:

$J_{w l}=T F_{C l} / r_{C l}$

where $J_{w l}$ is the water flux, in $\mathrm{mm} \bullet \mathrm{y}^{-1}$, at layer $l$; $T F_{C l}$ is $\mathrm{Cl}^{-} \mathrm{TF}$ deposition, in $\mathrm{mg} \cdot \mathrm{m}^{-2} \cdot \mathrm{y}^{-1}$; and $r_{\mathrm{Cl}}$ is the median $\mathrm{Cl}^{-}$soil solution concentration at $l$, in $\mathrm{mg} \mathrm{l}^{-1}$. Calculations were performed based on both DYs and the entire sampling period. The flux of each ion, $J_{i l}$, was calculated by multiplying the relevant $J_{w l}$ value for the median soil solution concentration, $r_{i l}$, for the same layer and period. The overall budget for each ion $\left(B_{i}\right)$ was then calculated as follows:
$B_{i}=T D_{i}-J_{i s}$

where $s$ is the subsoil layer of the deepest samplers.

\subsection{Statistical analysis}

Relations between yearly BCE TF deposition and BD, TFH and BDH were tested using Spearman correlation analysis. Linear regressions were performed between the estimated subsoil water fluxes $\left(J_{w s}\right)$ and the recorded volumes of throughfall (TF) precipitation.

\section{Results and discussion}

\subsection{BCE deposition and canopy budgets}

Bulk and throughfall deposition of BCEs (Table 3) followed a south-north decreasing pattern with high values to the south declining to fairly low values in the Alps; the lowest deposition rate at PIE1 and the somewhat low values at EMI1 were likely due to a shadow effect of the Apennines on the southern deposition sources. Seasonal variability trends differed among the various elements. $\mathrm{Na}^{+}$and $\mathrm{Cl}^{-}$showed clear summer minima, corresponding to the minimum strength of the westerlies blowing across the Mediterranean, thus reducing marine aerosol transport. Throughfall $\mathrm{K}^{+}$deposition showed two maxima, in late spring and fall; this seasonality can be linked to leaf area, with the secondary summer minimum caused by low precipitation. $\mathrm{Ca}^{2+}$ and $\mathrm{Mg}^{2+}$ showed summer maxima instead, associated with prevailing southerly winds (Rogora et al., 2004). These trends supported a major role of marine aerosol and Saharan dust transport in BCE deposition. Deposition of Saharan calcareous dust, as a factor controlling acidification and recovery, has also been recorded for a northern site in Italy (Rogora et al., 2004) and for southern Spain (Morales-Baquero et al., 2013).

The canopy budget model was not fully applicable to all plots; at VEN1, the DDF values for $\mathrm{Na}^{+}$were close to 1 ; thus, TD was assumed to be equal to $\mathrm{BD}$. A comparison with the results obtained at the other sites (Table 3 ) suggests that this may have resulted in some underestimation of $\mathrm{Ca}^{2+}$ deposition. For EMI, LAZ1 and PIE1, a canopy budget with a shorter time series had previously been assessed by Balestrini et al. (2007); they found some constraints in the application of the model for the LAZ1 and PIE1 sites. At LAZ1, they decided to use $\mathrm{Ca}^{2+}$ as a tracer instead of $\mathrm{Na}^{+}$due to the high net throughfall of $\mathrm{Na}^{+}$with respect to other cations as well as the closer linear relation between $\mathrm{BD}$ and $\mathrm{TF}$ for $\mathrm{Ca}^{2+}$ than for $\mathrm{Na}^{+}$. In our longer time series, however, we found very similar relations between bulk and throughfall fluxes for $\mathrm{Na}^{+}$and $\mathrm{Ca}^{2+}$ (Table 4). Furthermore, the use of $\mathrm{Ca}^{2+}$ as tracer ion would have resulted in higher, less conservative TD estimates with respect to the mixed method that we used. The constraint found for PIE1, i.e., BD exceeding TFD for $\mathrm{Na}^{+}$, did not exist for our longer time series in which the throughfall deposition of $\mathrm{Na}^{+}$was slightly higher than bulk deposition, thus allowing the dry deposition factor to be calculated. In this high-rainfall and fairly inland site, BCE input due to dry deposition was minimal.

Potassium, followed by $\mathrm{Ca}^{2+}$, was the most abundant BCE in TF deposition at all sites except LAZ1, in which $\mathrm{Na}^{+}$was the most abundant due to proximity to the Mediterranean Sea (Fig. 1). Canopy leaching (CL) appeared as the dominant source of $\mathrm{K}^{+}$(Table 3 ), while it poorly contributed to $\mathrm{Ca}^{2+} \mathrm{TFD}$, for which the largest component originated from bulk and dry deposition; a balance between $\mathrm{Ca}^{2+}$ DD and CL was only found at EMI1. Interpretation of the canopy budget results was supported by several observations. For the LAZ1, EMI1 and VEN1 sites, the Spearman correlation coefficients (Table 4) evidenced a high correlation between $\mathrm{BD}$ and $\mathrm{TF}$ deposition of $\mathrm{Ca}^{2+}$ and $\mathrm{Mg}^{2+}$, while no significant correlation was found with precipitation volumes $\mathrm{BDH}$ and 
Table 7.

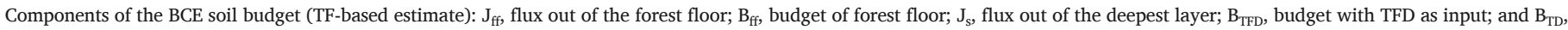
overall budget with TD as input. Units are in $\mathrm{g} \bullet \mathrm{m}^{-2} \bullet \mathrm{y}^{-1}$.

\begin{tabular}{|c|c|c|c|c|c|c|c|}
\hline \multicolumn{2}{|c|}{ TD as input. Units are in $\mathrm{g} \cdot \mathrm{m}^{-2} \cdot \mathrm{y}^{-1}$. Input $\left(\mathrm{g} \cdot \mathrm{m}^{-2} \cdot \mathrm{y}^{-1}\right)$} & \multicolumn{3}{|c|}{ Output $\left(\mathrm{g} \cdot \mathrm{m}^{-2} \cdot \mathrm{y}^{-1}\right)$} & \multicolumn{3}{|c|}{ Budget $\left(\mathrm{g} \cdot \mathrm{m}^{-2} \cdot \mathrm{y}^{-1}\right)$} \\
\hline Site & TFD & $\mathrm{TD}$ & Jff & Js & Bff & Bs (TF) & Bs (TD) \\
\hline \multirow[t]{4}{*}{$\mathrm{K}$} & $1.59 \pm 0.33$ & 0.35 & 2.28 & 0.02 & -0.68 & 1.58 & 0.33 \\
\hline & & 1.53 & & & & & \\
\hline & & 0.32 & & & & & \\
\hline & & 1.98 & & & & & \\
\hline $\mathrm{Ca}$ & $1.58 \pm 0.40$ & 3.48 & 0.42 & -1.89 & 1.17 & 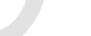 & 1.11 \\
\hline LAZ1 & $\mathrm{Mg}$ & $0.43 \pm 0.08$ & 1.22 & 0.56 & -0.78 & -0.12 & -0.24 \\
\hline $\mathrm{Na}$ & $1.98 \pm 0.38$ & 2.04 & 2.39 & 0.01 & -0.33 & & -0.41 \\
\hline BCE & $5.58 \pm 0.93$ & 4.18 & 9.02 & 3.39 & -3.34 & 2.28 & 0.79 \\
\hline \multirow[t]{4}{*}{$\mathrm{K}$} & $1.62 \pm 0.19$ & 0.18 & 1.00 & 0.00 & 0.61 & 1.61 & 0.18 \\
\hline & & 0.84 & & & & & \\
\hline & & 0.13 & & & & & \\
\hline & & 0.53 & & & 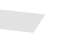 & & \\
\hline $\mathrm{Ca}$ & $1.14 \pm 0.28$ & 2.67 & 0.85 & -1.54 & 0.29 & & -0.01 \\
\hline EMI1 & $\mathrm{Mg}$ & $0.27 \pm 0.03$ & 1.02 & 0.34 & -0.75 & -0.06 & -0.21 \\
\hline $\mathrm{Na}$ & $0.53 \pm 0.10$ & 0.66 & 0.88 & -0.14 & -0.35 & & -0.35 \\
\hline BCE & $3.56 \pm 0.41$ & 1.68 & 5.36 & 2.07 & -1.81 & 1.49 & -0.39 \\
\hline \multirow[t]{4}{*}{$\mathrm{K}$} & $0.68 \pm 0.19$ & 0.10 & - & 0.02 & - & 0.66 & 0.08 \\
\hline & & 0.29 & & & & & \\
\hline & & 0.04 & 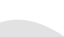 & & & & \\
\hline & & 0.19 & & & & & \\
\hline $\mathrm{Ca}$ & $0.30 \pm 0.17$ & - & 0.22 & - & 0.08 & & 0.07 \\
\hline PIE1 & $\mathrm{Mg}$ & $0.06 \pm 0.03$ & - & 0.08 & - & -0.03 & -0.04 \\
\hline $\mathrm{Na}$ & $0.19 \pm 0.12$ & - & 0.18 & - & 0.01 & & 0.01 \\
\hline BCE & $1.23 \pm 0.49$ & 0.62 & - & 0.50 & 0.72 & & 0.12 \\
\hline \multirow[t]{3}{*}{$\mathrm{K}$} & $1.54 \pm 0.42$ & 0.45 & 1.32 & 0.03 & 0.22 & 1.51 & 0.42 \\
\hline & & 0.38 & & & & & -0.73 \\
\hline & & 0.07 & & & & & -0.07 \\
\hline $\mathrm{Ca}$ & $0.76 \pm 0.34$ & 3.30 & & 1.11 & -2.54 & & -0.35 \\
\hline VEN1 & $\mathrm{Mg}$ & $0.14 \pm 0.05$ & 0.34 & 0.14 & -0.20 & & -0.00 \\
\hline
\end{tabular}

TFH). This suggested a common precipitation-independent source for $\mathrm{Ca}^{2+}$ and $\mathrm{Mg}^{2+}$. Conversely, significant correlations at PIE1 were found between precipitation and deposition of all BCEs, indicating that precipitation was the driving factor of BCE input. The correlation found between $\mathrm{K}^{+}$and precipitation at all sites (Table 4) indicated the role of rainfall in enhancing canopy $\mathrm{K}^{+}$leaching. The obtained individual cation budgets are comparable to the results of Aguillaume et al. (2017) for holm oak forest sites in Spain.

\subsection{Composition of soil solutions}

Average concentrations of $\mathrm{Cl}^{-}$and BCEs in soil solutions for each site and sampling depth are reported in Table 5. Standard deviations between different sampler replicas were calculated for each depth at each sampling time as an indicator of the spatial variability of soil solution chemistry within each site. The BCE concentrations varied consistently with the observed trends in deposition and precipitation. Variability between replicates within each site was often one order of magnitude smaller than the average; the highest variability was found in sampler sets with very low average concentrations close to the quantification limits, as defined by the UNECE-ICP (2016).

\subsection{Estimated water fluxes}

The average results for the entire period at each site are compared in Table 6. The estimated water fluxes were rather consistent with the climatic conditions of the sites. The estimated subsoil water fluxes were compared with the recorded TF precipitation on a DY basis (Fig. 2), showing a significant positive correlation at both LAZ1 and PIE1. At the VEN1 and EMI1 sites, the correlations were meaningless due to the essentially constant TF precipitation volume and estimates subsoil water flow, respectively. We interpreted these features as characteristic of the climatic conditions of these two sites. At VEN1, because rainfall is substantially higher than ETP (Fig. 1), water flux changes were due to the variability of evapotranspiration under constant precipitation and controlled by other climatic factors. On the other hand, ETP at EMI1 was higher than rainfall; thus, the estimated water fluxes represented a rainfall fraction that could not be used by vegetation, such as winter precipitation; any excess rainfall over such fraction was used for evapotranspiration, resulting in constant estimated water fluxes.

\subsection{BCE budgets}

The estimated BCE budgets are reported in Table 7. Forest floor budgets $\left(\mathrm{B}_{\mathrm{ff}}\right)$ were consistent with and supported the canopy budget estimates. Potassium FF budgets were approximately neutral, with $\mathrm{K}^{+}$being retained at EMI1 and VEN1; these results suggested that most foliar $\mathrm{K}^{+}$was transferred to the forest floor through canopy leaching and $\mathrm{TF}$ deposition. A negative $B_{\mathrm{ff}}$ was seen for both calcium and magnesium, for which the FF output $\left(\mathrm{J}_{\mathrm{ff}}\right)$ was much higher than TF deposition; this result implied that foliar $\mathrm{Ca}^{2+}$ and $\mathrm{Mg}^{2+}$ were mainly released after abscission and leaf fall. For these cations, the input to the soil due to net forest floor release $\left(\mathrm{B}_{\mathrm{ff}}<0\right)$ was close to or even higher than the input from throughfall deposition, thus evidencing the high contribution of $\mathrm{BCE}$ recycling through vegetation.

The overall budget with TD as input $\left(\mathrm{B}_{\mathrm{TD}}\right)$ for potassium suggested that $\mathrm{K}^{+}$was retained and accumulated at all sites, which indicated the combined efficiency of soil retention by clay minerals and vegetation uptake. The magnesium budgets were, on the other hand, always negative. Soil $\mathrm{Mg}^{2+}$ retention appeared inefficient, particularly at PIE1, where the soil exhibited the lowest clay content (Table 2). Sodium also showed a general loss trend. The $\mathrm{Na}^{+}$flux increased through the mineral soil at EMI1 and LAZ1 $\left(\mathrm{J}_{\mathrm{s}}>\mathrm{J}_{\mathrm{ff}}\right)$, suggesting a contribution from weathering; at EMI1, a negative budget for the forest floor suggested 
instead a contribution from dry deposition falling directly on the ground.

Calcium was strongly retained at LAZ1 $\left(B_{\mathrm{TD}}=1.11 \mathrm{~g} \cdot \mathrm{m}^{-2} \cdot \mathrm{y}^{-1}\right)$ and showed an approximately even budget at EMI $\left(\mathrm{B}_{\mathrm{TD}}=-0.01 \mathrm{~g} \cdot \mathrm{m}^{-2} \cdot \mathrm{y}^{-1}\right)$. At PIE1, the small estimated positive budget was likely reversed by leaching in winter (not covered by soil solution sampling), when precipitation was higher and $\mathrm{Ca}^{2+}$ deposition lower. Finally, a net ongoing loss was evidenced at VEN1, even without collecting samples during winter. The marked differences in $\mathrm{Ca}^{2+}$ budgets were consistent with the deposition levels, climatic conditions and soil characteristics of the sites. $\mathrm{Ca}^{2+}$ accumulation at LAZ1 was made possible by high deposition, low water fluxes and high soil retention in a soil with high CEC and low base saturation (BS). At EMI1, lower deposition and CEC contributed to an even budget. The soil at the VEN1 site was the least Ca-retaining one due to the combined effects of high precipitation, high BS and easy plant calcium availability from both the soil and the calcareous substrate. PIE1 appeared to lose comparably less $\mathrm{Ca}^{2+}$, notwithstanding lower deposition and higher precipitation due to low $\mathrm{BS}$ and low $\mathrm{Ca}^{2+}$ plant availability.

As a final result, the overall BCE budgets were positive for LAZ1, neutral for PIE1, and negative by small margins for the other sites.

\section{Conclusions}

Though our results represented a preliminary estimation, they clearly indicate that atmospheric deposition of basic exchangeable cations in Italian forest soils is a major process, influencing both forest nutrition and soil development. Potassium is retained in all conditions. Calcium retention varies with deposition, climatic and soil conditions, while deposition input is always significant for the soil-forest system equilibrium. Magnesium is the only essential nutrient that undergoes general loss, although deposition significantly reduces the loss rate.

The acidification of forest soils appears to be prevented in south-central Italy and markedly mitigated in northern Italy by the present regime of BCE atmospheric deposition, which has been ongoing since the middle Holocene (Le Roux et al., 2012; Ehrmann et al., 2017).

Acidic soils in the ETP $>$ P area of Italy, which are not rare, should have acidified under different environmental conditions, including higher precipitation and/or lower deposition of BCEs, such as the extended periods of low Saharan dust deposition, as reported by Ehrmann et al. (2017) in the central Mediterranean Sea.

\section{Uncited reference}

Bonifacio et al., 1997

\section{Acknowledgments}

This research was partly funded by the European Union under the Regulation (EC) No 2152/2003 of the European Parliament and of the Council of 17 November 2003 concerning monitoring of forests and environmental interactions in the community (Forest Focus), and the LIFE projects FutMon ("Further Development and Implementation of an EU-level Forest. Monitoring System". LIFE07 ENV/D/000218) and SMART4Action ("Sustainable Monitoring and Reporting To Inform Forest- and Environmental Awareness and Protection". LIFE13 ENV/IT/ 000813).

\section{References}

Aguillaume, L., Izquieta-Rojano, S., García-Gómez, H., Elustondo, D., Santamaría, J.M., Alonso, R. Avila, A., 2017. Dry deposition and canopy uptake in Mediterranean holm-oak forests estimated with a canopy budget model: a focus on $\mathrm{N}$ estimations. Atmos. Environ. 152, 191-200.
Albani, S., Mahonwald, N.M., Winckler, G., Anderson, R.F., Bradtmiller, L.I., Delmonte, B., François, R., Goman, M., Heavens, N.G., Hesse, P.P., Hovan, S.A., Gang, S.G., Kohfeld, K.E., Lu, H., Maggi, V., Mason, J.A., Mayewski, P.A., McGee, D., Miao, X., Otto-Bliesner, B.L., Perry, A.T., Pourmand, A., Roberts, H.M., Rosenbloom, N., Stevens, T., Sun, J., 2015. Twelve thousand years of dust: the Holocene global dust cycle constrained by natural archives. Clim. Past 11, 869-903.

Alewell, C., Manderscheid, B., Gerstberger, P., Matzner, E., 2000. Effects of reduced atmospheric deposition on soil solution chemistry and elemental contents of spruce needles in NE-Bavaria, Germany. J. Plant Nutr. Soil Sci. 163, 509-516.

Avila, A., Peňuelas, J., 1999. Increasing frequency of Saharan rains over northeastern Spain and its ecological consequences. Sci. Total Environ. 228, 153-156.

Avila, A., Rodà, F., 1991. Red rain as major contributors of nutrients and alkalinity to terrestrial ecosystems at Montseny (NE Spain). Orsis 6, 215-229.

Balestrini, R., Arisci, S., Brizzio, M.C., Mosello, R., Rogora, M., Tagliaferri, A., 2007. Dry deposition of particles and canopy exchange: comparison of wet, bulk and throughfall deposition at five forest sites in Italy. Atmos. Environ. 41, 745-756.

Bertini, G., Amoriello, T., Fabbio, G., Piovosi, M., 2011. Forest growth and climate change: evidences from the ICP-forests intensive monitoring in Italy. IForest 4, 262-267.

Bonifacio, E., Zanini, E., Boero, V., Franchini-Angela, M., 1997. Pedogenesis in a soil catena on serpentinite in north-western Italy. Geoderma 75, 33-51.

Brahy, V., Deckers, J., Delvaux, B., 2000. Estimation of soil weathering stage and acid neutralizing capacity in a toposequence Luvisol-Cambisol on loess under deciduous forest in Belgium. Eur. J. Soil Sci. 51, 1-13.

Carnicelli, S., Costantini, E.A.C., 2013. Time as a soil forming factor and age of Italian soils. In: Costantini, E.A.C., Dazzi, C. (Eds.), The Soils of Italy. Springer Science + Business Media, Dordrecht, pp. 93-104.

Carnicelli, S., Benvenuti, M., Andreucci, S., Ciampalini, R., 2015. Late Pleistocene relic Ultisols and Alfisols in an alluvial fan complex in coastal Tuscany. Quat. Int. 376, 163-172.

Chadwick, O.A., Chorover, J., 2001. The chemistry of pedogenic thresholds. Geoderma $100,321-353$

Chadwick, O.A., Derry, L.A., Vitousek, P.M., Huebert, B.J., Hedin, L.O., 1999. Changing sources of nutrients during four million years of ecosystem development. Nature 397, 491-497.

Chesworth, W., 1983. The haplosoil system. Am. J. Sci. 280, 969-985.

Chesworth, W., 1992. Weathering systems. In: Martini, P., Chesworth, W. (Eds.), Weathering, Soils \& Paleosols. Dev. Earth Surface Processes. vol. 2, p. 19.

Costantini, E.A.C., Carnicelli, S., Sauer, D., Priori, S., Andreetta, A., Kadereit, A., Lorenzetti, R., 2018. Loess in Italy: genesis, characteristics and occurrence. Catena 168 , $14-33$.

Eger, A., Almond, P.C., Wells, A., Condron, L.M., 2013. Quantifying ecosystem rejuvenation: foliar nutrient concentrations and vegetation communities across a dust gradien and a chronosequence. Plant Soil 367, 93-109.

Ehrmann, W., Schmiedl, G., Beuscher, S., Krüger, S., 2017. Intensity of African humid periods estimated from Saharan dust fluxes. PLoS One 12 (1), e0170989.

Field, J.P., Belnap, J., Breshears, D.D., Neff, J.C., Okin, G.S., Whicker, J.J., Painter, T.H., Ravi, S., Reheis, M.C., Reynolds, R.L., 2010. Front. Ecol. Environ. 8, 423-430.

Folster, J., Bringmark, L., Lundin, L., 2003. Temporal and spatial variations in soilwater chemistry at three acid forest sites. Water Air Soil Pollut. 146, 171-195.

Guerzoni, S., Chester, R., Dulac, F., Herut, B., Loÿe-Pilot, M.-D., Measures, C., Migon, C., Molinaroli, E., Moulin, C., Rossini, P., Saydam, C., Soudine, A., Ziveri, P., 1999. Prog. Oceanogr. 44, 147-190.

Herbillon, A.J., 1986. Chemical estimation of weatherable minerals present in the diag nostic horizons of low activity clay soils. In: Beinroth, F.H., Camargo, M.N., Eswaran, H. (Eds.), Proceedings of the 8th International Classification Workshop: Classification, Characterization and Utilization of Oxisols. Part I. EMBRAPA, Rio de Janeiro, pp. 39-48.

Hruška, J., Ouhlele, F., Šamonil, P., Šebesta, J., Tahovská, K., Hleb, R., Houška, J. Šikl, J., 2012. Long-term forest soil acidification, nutrient leaching and vegetation development: linking modelling and surveys of a primeval spruce forest in the Ukrainian Transcarpathian Mts. Ecol. Model. 24, 28-37.

Hynicka, J.D., Pett-Ridge, J.C., Perakis, S.S., 2016. Nitrogen enrichment regulates calcium sources in forests. Glob. Chang. Biol. 22, 4067-4079.

Iamarino, M., Terribile, F., 2008. The importance of andic soils in mountain ecosystems: a pedological investigation in Italy. Eur. J. Soil Sci. 59, 1284-1292.

IUSS Working Group WRB, 2006. World Reference Base for Soil Resources. vol. 103, World Soil Resources Reports, Rome, (132 pp).

Johnson, J., Graf Pannatier, E., Carnicelli, S., Cecchini, G., Clarke, N., Cools, N., Hansen, K., Meesenburg, H., Nieminen, T.M., Pihl-Karlsson, G., Titeux, H., Vanguelova, E., Verstraeten, A., Vesterdal, L., Waldner, P., Jonard, M., 2018. The response of soil solution chemistry in European forests to decreasing acid deposition. Glob. Chang. Biol. 24 (8), 3603-3619.

Kishcha, P., Nickovic, S., Starobinets, B., di Sarra, A., Udisti, R., Becagli, S., Sferlazzo, D., Bommarito, C., Alpert, P., 2011. Sea-salt aerosol forecasts compared with daily measurements at the island of Lampedusa (Central Mediterranean). Atmos. Res. 100, 28-35.

König, N., Cools, N., Derome, K., Kowalska, A., De Vos, B., Fürst, A., Marchetto, A., O'Dea, P., Tartari, G.A., 2013. Chapter 22 - data quality in laboratories: methods and results for soil, foliar, and water chemical analyses. In: Ferretti, M., Fischer, R. (Eds.), Developments in Environmental Science. Elsevier.

Le Roux, G., Fagel, N., De Vleeschouwer, F., Krachler, M., Debaille, V., Stille, P., Mattielli, N., van der Knaap, W.O., F.N. van Leeuwen, J., Shotyk, W., 2012. Volcano- and cli- 
mate-driven changes in atmospheric dust sources and fluxes since the Late Glacial in Central Europe. Geology 40, 335-338.

Lee, D.S., Kingdon, R.D., Pacyna, J.M., Bouwman, A.F., Tegen, I., 1999. Modelling base cations in Europe, sources, transport and deposition of calcium. Atmos. Environ. 33, 2241-2256.

Lequy, E., Conil, S., Turpault, M.-P., 2012. Impact of aeolian dust deposition on European forest sustainability: a review. For. Ecol. Manag. 267, 240-252.

Likens, G.E., Driscoll, C.T., Buso, D.C., 1996. Long-term effects of acid rains: response and recovery of a forest ecosystem. Science $272,244-246$.

Macias, F., Camps Arbestain, M., Chesworth, W., 2008. Acid soils. in Chesworth, W. (ed.): Encyclopaedia of Soil Science. Springer, Dordrecht, NL, pp. 9.

Maestrelli, D., Benvenuti, M., Bonini, M., Carnicelli, S., Piccardi, L., Sani, F., 2018. The structural hinge of a chain-foreland basin: quaternary activity of the Pede-Apennine Thrust front (Northern Italy). Tectonophysics 723, 117-135.

Manca, F., Capelli, G., Tuccimei, P., 2015. Sea salt aerosol groundwater salinization in the Litorale Romano Natural Reserve (Rome, Central Italy). Environ. Earth Sci. 73, 4179-4190.

Marchetto, A., Mosello, R., Tartari, G., Derome, J., Derome, K., König, N., Clarke, N., Kowalska, A., 2011. Atmospheric deposition and soil solution working ring test 2011. Laboratory ring test for deposition and soil solution sample analyses for the laboratories participating in the EU/Life + Fut Mon Project. In: CNR-ISE Report 06. vol. 11, Verbania Pallanza, Italy, pp. 13-15.

Meesenburg, H., Ahrends, B., Fleck, S., Wagner, M., Fortmann, H., Scheler, B., Klinck, U., Dammann, I., Eichhorn, J., Mindrup, M., Meiwes, K.J., 2016. Long-term changes of ecosystem services at Solling, Germany: recovery from acidification, but increasing nitrogen saturation?. Ecol. Indic. 65, 103-112.

Mileti, F.A., Langella, G., Prins, M.A., Vingiani, S., Terribile, F., 2013. The hidden nature of parent material in soils of Italian mountain ecosystems. Geoderma 207-208, 291-309.

Morales-Baquero, R., Pulido-Villena, E., Reche, I., 2013. Chemical signature of Saharan dust on dry and wet atmospheric deposition in the south-western Mediterranean region. Tellus Ser. B Chem. Phys. Meteorol. 65, 2-11.

Mosello, R., Amoriello, M., Amoriello, T., Arisci, S., Carcano, A., Clarke, N., Derome, J., Derome, K., Koenig, N., Tartari, G., Ulrich, E., 2005. Validation of chemical analyses of atmospheric deposition in forested European sites. J. Limnol. 64, 93-102.

Robarge, W.P., Johnson, D.W., 1992. The effects of acidic deposition on forested soils. Adv. Agron. 47, 1-83.

Rogora, M., Mosello, R., Marchetto, A., 2004. Long-term trends in the chemistry of atmospheric deposition in northwestern Italy: the role of increasing Saharan dust deposition. Tellus Ser. B Chem. Phys. Meteorol. 56, 426-434.

Slessarev, E.W., Bingham, N.L., Johnson, J.E., Dai, Y., Schimel, J.P., Chadwick, O.A., 2016. Water balance creates a threshold in soil pH at the global scale. Nature 540, 567-569.

Smith, G.D., 1986. The Guy Smith Interviews: Rationale for Concepts in Soil Taxonomy. SMSS Technical Monograph 11. USDA-SSMS, Washington DC., USA.
Staelens, J., Houle, D., De Schrjiver, A., Neyrinck, J., Verheyen, K., 2008. Calculating dry deposition and canopy exchange with the canopy budget model: review of assumptions and application to two deciduous forests. Water Air Soil Pollut. 191, 149-169.

Staff, Soil Survey, 1999. Soil Taxonomy: A Basic System of Soil Classification for Making and Interpreting Soil Surveys, Second Edition. Agriculture Handbook, No. 436. Natural Resources Conservation Service. United States Department of Agriculture.

Stuut, J.-B., Smalley, I., O'Hara-Dhand, K., 2009. Aeolian dust in Europe: African sources and European deposits. Quat. Int. 198, 234-245.

Talkner, U., Krämer, I., Hölscher, D., Beese, F.O., 2010. Deposition and canopy exchange processes in central-German beech forests differing in tree species diversity. Plant Soil 336, 405-420.

Tomlinson, G.H., 2003. Acidic deposition, nutrient leaching and forest growth. Biogeochemistry $65,51-81$.

Ulrich, B., 1983. Interaction of Forest Canopies With Atmospheric Constituents: $\mathrm{SO}_{2}$, Alkali and Alkali Earth Cations and Chloride. Effects of Accumulations of Air Pollutants in Forest Ecosystems. Reidel Publishing Company, Dordrecht, 35-45.

Ulrich, B., 1986. Natural and anthropogenic components of soil acidification. Z. Pflanzenernähr. Bodenkd. 149, 702-717.

UNECE-ICP, 2016. Manual on methods and criteria for harmonized sampling, assessment, monitoring and analysis of the effects of air pollution on forests. In: Part XI: Soil Solution Collection and Analysis. https://www.icp-forests.org/pdf/manual/2016/ICP Manual_2016_01_part11.pdf.

Van Breemen, N., Mulder, J., Driscoll, C.T., 1983. Acidification and alkalinization of soils. Plant Soil 75, 283-308.

Vanguelova, E.I., Benham, S., Pitman, R., Moffat, A.J., Broadmeadow, M., Nisbet, T., Durrant, D., Barsoum, N., Wilkinson, M., Bochereau, F., Hutchings, T., Broadmeadow, S., Crow, P., Taylor, P., Houston, T.D., 2010. Chemical fluxes in time through forest ecosystems in the UK - soil response to pollution recovery. Environ. Pollut. 158, 1857-1869.

Vet, R., Artz, R.S., Carou, S., Shaw, M., Chul-Un, R., Aas, W., Baker, A., Bowersox, V.C., Dentener, F., Galy-Lacaux, C., Hou, A., Pienaar, J.J., Gillett, R., Forti, M.C., Gromov, S., Hara, H., Khodzher, T., Mahowald, N.M., Nickovic, S., Rao, P.S.P., Reid, N.W., 2014. A global assessment of precipitation chemistry and deposition of sulfur, nitrogen, sea salt, base cations, organic acids, acidity and $\mathrm{pH}$, and phosphorus. Atmos. Environ. 93 (3-100),

Vet, R., Artz, R.S., Carou, S., Shaw, M., Chul-Un, R., Aas, W., Baker, A., Bowersox, V.C., Dentener, F., Galy-Lacaux, C., Hou, A., Pienaar, J.J., Gillett, R., Forti, M.C., Gromov, S., Hara, H., Khodzher, T., Mahowald, N.M., Nickovic, S., Rao, P.S.P., Reid, N.W., 2014. Addendum to: "A global assessment of precipitation chemistry and deposition of sulfur, nitrogen, sea salt, base cations, organic acids, acidity and $\mathrm{pH}$, and phosphorus". Atmos. Environ. 93, 101-116.

Watmough, S.A., Whitfield, C.J., Fenn, M.E., 2014. The importance of atmospheric base cation deposition for preventing soil acidification in the Athabasca Oil Sands Region of Canada. Sci. Total Environ. 493, 1-11. 